\title{
REREADING CHRISTIAAN SNOUCK HURGRONJE: HIS ISLAM, MARRIAGE AND INDO-EUROPEAN DESCENTS IN THE EARLY TWENTIETH-CENTURY PRIANGAN
}

\author{
JAJANG A ROHMANA ${ }^{1}$ \\ Universitas Islam Negeri Sunan Gunung Djati Bandung
}

\section{Abstract}

This study focuses on a controversial issue about Christiaan Snouck Hurgronje's family that was left in the Dutch East Indies in the early twentieth century. The issue sparked a debate among scholars in the 1980s. The debate was concerned with the Dutch government's denial of Hurgronje's marriage to an Indigenous woman as it was intended to maintain his good reputation. As a matter of fact, the colonial government forbids the marriage of European people with Indigenous women because it would tarnish their status and make it difficult in their careers. This study is meant as a follow-up of van Koningsveld's findings about Hurgronje's wife and children in Priangan. Here the writer uses a historical analysis of the letters written by Hasan Mustapa to Hurgronje (Cod. Or. 8952). He argues that Hurgronje's history needs to be read in his position as a colonial official who may be worried about rules set by the colonial government. This study shows that Hurgronje cannot be considered completely irresponsible to his Indo-European family in the Dutch East Indies. In fact, he continued to monitor the condition of his family through regular correspondence with Hasan Mustapa, his close friend in the Dutch East Indies. This study is important in a sense that it is expected to be able to rectify the confusion over the issue of Hurgronje's morality towards his

Corresponding author; email: ${ }^{1}$ jajang_abata@yahoo.co.id. 


\section{JAJANG A ROHMANA}

family. It offers another perspective of the history of colonialism dealing with interracial relation between Indigenous women, and their offspring, and European men amid the rise of the issue of Nyai and concubinage in the Dutch East Indies.

Studi ini mengkaji masalah kontroversial tentang keluarga Christiaan Snouck Hurgronje yang ditinggalkan di Hindia Belanda pada awal abad kedua puluh. Masalah ini memicu perdebatan di kalangan sarjana pada 1980-an. Perdebatan tersebut berkaitan dengan penolakan pemerintah Belanda terhadap pernikahan Hurgronje dengan seorang perempuan Pribumi untuk mempertahankan reputasinya yang baik. Faktanya, pemerintah kolonial melarang pernikahan orang-orang Eropa dengan perempuan Pribumi karena hal itu akan merusak status mereka dan menyulitkan dalam karier mereka. Penelitian ini dimaksudkan sebagai tindak lanjut dari temuan van Koningsveld tentang istri dan anak Hurgronje di Priangan. Di sini penulis menggunakan analisis historis dari surat-surat yang ditulis oleh Hasan Mustapa kepada Hurgronje (Cod. Or. 8952). Dia berpendapat bahwa sejarah Hurgronje perlu dibaca dalam posisinya sebagai pejabat kolonial yang mungkin khawatir tentang aturan yang ditetapkan oleh pemerintah kolonial. Studi ini menunjukkan bahwa Hurgronje tidak dapat dianggap sepenubnya tidak bertanggung jawab terhadap keluarga Indo-Eropa di Hindia Belanda. Bahkan, ia terus memantau kondisi keluarganya melalui korespondensi rutin dengan Hasan Mustapa, teman dekatnya di Hindia Belanda. Penelitian ini penting dalam arti bahwa diharapkan dapat memperbaiki kebingungan tentang masalah moralitas Hurgronje terhadap keluarganya. Tulisan ini menawarkan perspektif lain dari sejarah kolonialisme yang berurusan dengan hubungan antar-ras antara perempuan pribumi, keturunan mereka, dan laki-laki Eropa di tengah munculnya masalab Nyai dan pergundikan di Hindia Belanda.

Keywords: Hasan Mustapa; history; indigenous; letters; Snouck Hurgronje.

\section{Introduction}

In the 1980s, papers revealing the motives of Christiaan Snouck Hurgronje's (1857-1936) Islam, marriage, and descent 
in the Dutch East Indies in the late of the $19^{\text {th }}$ century by van Koningsveld, now an emeritus professor at the University of Leiden, invited controversy among scholars. Hurgronje was believed not to sincerely convert to Islam, and his conversion was merely an outward appearances (izh ār al-Islām). His Islam was intended to facilitate his infiltration into the Indonesian Muslim community. He easily entered Mecca that it is forbidden to non-Muslims. Then it continues in The Dutch East Indies, including Sunda that made him easier to marry a girl who intentionally covered (van Koningsveld, 1989: 221) Snouck realized that in Islamic faith a non-Muslim male is forbidden to marry a Muslim or a Muslim woman (Sabiq, n.d.: 65). Therefore, there was no way to get into the heart of Muslims lives, besides converting to Islam and marry a Muslim woman.

In the beginning, van Koningsveld's beliefs as for Snouck's marriage news with the local girls had faltered when reading the objection of Governor-General in Batavia on the news of several media such as Soerabaja-courant, 9 and January 13, 1890, which described Snouck Hurgronje's marriage with Hoofd Penghulu or Chief Penghulu of Ciamis's daughter. Van Koningsveld also got denial "rumor" that derived from Snouck on the news as conveyed in a private letter to Herman Bavinck. He stated that the married was a Chief Penghulu's clerk. Snouck presence in Ciamis aimed to do research about the wedding ceremony (van Koningsveld, 1989: 160).

However, van Koningsveld's suspicion strengthened when getting information from some Muslims living in the Netherlands. They heard from Indonesian pilgrims in Mecca on Snouck's marriage with a Native woman from West Java. Van Koningsveld then did an investigation and was able to interview one of Snouck's children, Raden Joesoef. He ended his silence for more than fifty years of Snouck's wife and children 


\section{JAJANG A ROHMANA}

in Priangan (van Koningsveld 1983). Joesoef frankly admitted the wedding of Snouck in Ciamis with Sangkana in 1890, until blessed with four children: Salmah Emah, Oemar Gandaprawira, Aminah and Ibrahim. Sangkana was an only one daughter of Chief Penghulu of Ciamis, R. Muhammad Ta'ib. Snouck then married again after the death of Sangkana with Siti Sadijah and blessed with one child named R. Joesoef. Siti Sadijah was the daughter of vice Chief Penghulu of Bandung, RH Muhammad Su'eb known as Apo Kalipah and now the name of the street in Bandung (van Koningsveld, 1989: 159-61).

The allegation of van Koningsveld on Snouck welcomes comments and criticism from some scholars. For two years occurred fairly heated debates in a number of media in the Netherlands such as the student newspaper, Mare, then the NRC (Nieuw Rotterdam Courant) and De Gids, seasoned and authoritative magazine in Dutch society (Kartodirdjo, 1988: 265). Schröder (1980) and Graf (1980), for example, provided another perspective related to the allegations. For them, Snouck proved to be a Muslim and concealed his Islam to the Dutch authorities, as it would intersect with his career. Therefore, we do not need to take God's right to judge Snouck's Islamic motivation. On this basis also, according to Witkam, Snouck's wedding with Sundanese girl held by Islamic law and maintained the confidentiality that was not known by The Dutch East Indies officials. So it was very reasonable when Snouck's wife and children lacked proper of education because his marriage was not approved by the colonial government (Carvalho, 2010: 112-3).

This paper contributes to the study of Snouck's life history, especially related to information about the fate of his wife and children after he left for the Netherlands in 1906. I agree with van Koningsveld about the truth information of Snouck's Islamic, marriage and his offspring in Priangan. However, un- 
like van Koningsveld sourced from a series of interviews on one of his offspring, this study uses personal letters of Hasan $\mathrm{Mu}$ stapa on Snouck between the years 1911-1923 were analyzed using the historical method. Hasan Mustapa (1852-1930) was a Chief Penghulu of Bandung which has been a long time being friends with Snouck. He is a prolific writer and a famous Sundanese Sufi who composed more than ten thousand stanzas of Sufi dangding. He met Snouck in Mecca then continued when Snouck settled in the Dutch East Indies (1889-1906) (Rohmana, 2015: 273-312; Rohmana, 2012: 303-27). With a commitment to remain mutual trust between friend and close family, Snouck relied on Mustapa to continue sending any information about his wife and children in The Dutch East Indies by mail after he returned to the Netherlands in 1906 (Jahroni, 1999; Rohmana, 2016: 144-68). These letters in Arabic script recorded in Universteit Bibliotheek Leiden with code Cod. Or 8952. The letters of Hasan Mustapa historically has an important position considering the information about the family that was expected by Snouck.

However, I am also critical to the van Koningsveld's allegation (1989) on Snouck considered "let his own offspring as lower class", in its efforts to improve the education level of Natives. The accusation may be less precise when reading such Snouck's great attention to his wife and children's circumstances from time to time as envisaged in Hasan Mustapa's letters and his powerlessness to confront the colonial government regulations. Psychologically, the information comes from Hasan Mustapa was believed to be able to provide peace of mind for Snouck as a husband and father to five children living in Priangan. Information may be deliberately did not want to be known by anyone other than himself and his informant. This matter which in postcolonialism study of Edward Said becomes representative 


\section{JAJANG A ROHMANA}

example of deepest contact between colonial culture and its colonies (Said, 1994: 200).

\section{Who is Snouck Hurgronje?}

There have been many studies on the figure of Snouck. Some scholars have explained the biography of his life background, education and the contribution of his works. Carvalho has been documented all bibliographic posts growing for about an earlier century from the scholars in the context of orientalize in the Netherlands. He also tried to explain the life, ideals, kindness, sins, contradictions and some perceptions about Snouck developing among the scholars after the end of colonialism. Although he realized that all those things, however, not be able to explain fully what is actually perceived by Snouck (Carvalho, 2010: 5, 120).

Christiaan Snouck Hurgronje was born in 1857 in Oosterhout, Netherlands. After graduating from Hogere Burgerschool in Breda and taking the state exam. He attended Leiden University in 1874. There he learned Arabic and took the candidate examination in theology and Semitic languages. Then he continued his doctoral education in Semitic languages and was completed in 1879 with cum laude. His dissertation purely discussed textual study about the origins of the pilgrimage, Mekkaansche Het Feest (The Mecca Festivals) (Hurgronje, 1880; Hurgronje, 1989).

Snouck became an assistant professor at the Institute of Municipal Servants East Indies in Leiden from 1881 to 1887. This position was interrupted by his settled in Jidda and Mecca which was phenomenal from August 1884 to 1885. An experience called by Witkam as the most important episode in his life (Witkam, 2007: xx). He was interested in the daily lives of Muslims in the heart of the holy places which forbidden to non-Mus- 
lim. Snouck was believed to be converted to Islam and changed his name to Abdul Ghaffar. So it was not surprising that in a short time he would be accepted by Mecca. The result of his experience poured in two parts of German-language book which amazing, Mekka, contained photographs and customs review of the Mecca and the Muslims visited there ahead of the Haj season. Inside of this book, he told the daily life of inhabitants of Mecca, included his meeting with many people from Sumatra, Java, Kalimantan, Sulawesi, Maluku and other (Hurgronje, 2007: 231-312). One of those whom he met Hasan Haji Mustapa. In addition, it was reported that during stayed in Mecca, Snouck bought a slave girl and left her in a state of pregnancy.

Several years later, in May 1889, Snouck started the position of seconded employees to the Dutch government in Batavia. A year later, Snouck married to Sangkana, a daughter of Penghulu Ciamis, in 1890. In 1891-1893, he was then conducted research in Java, about the teaching of Islam in Pesantren and various circumstances occurred at that time. From July 16, 1891, until February 1892, Snouck stayed in Aceh and returned to live there in 1898-1901. He did some research on the language and customs in Aceh. The result of the research poured into important works, the Atjehers (Hurgronje 1906).

After returning to Java, Snouck, through the organized correspondence by the senders of the news in Aceh, including the Chief Penghulu of Aceh, Haji Hasan Mustapa, he fully awarded the situation there. In 1898, two years after Teuku Umar defected and General Deyckerhoff fired, and when Colonel Van Heutsz was appointed to be Governor of the Civil and Military Aceh, the Government gave a task to Snouck that was supposed to give him influenced that remains on the affairs of civil government there. However, due to differences in views, it ended cooperation with Van Heutsz in 1903 (Gobee, E. and Adriaanse, 1936: ix). 


\section{JAJANG A ROHMANA}

Earlier, at the beginning of 1901 Snouck reportedly often stayed in Jambi and Palembang. At the end of that year, he stayed a few weeks in Jambi. In 1903, after withdrawing from Aceh, he tried to organize a trip to Kerinci, on the border of the mountainous area of Padang. After he boarded the boat into the Pacific, at the confluence with the River Marangin and Mesuma, then he walked through a very difficult terrain which would take ten days to reach its destination. But he was forced to break his journey as a result of malaria attacks and back again. Based on data collected during the trip, Snouck was able to give his views in 1916 on the causes that led to rebellion in Jambi and Palembang. The data collected until the last of 1902 about Land of Gayo and its habitant had published in 1904 (Hurgronje 1902).

After about seventeen years living in the Dutch East Indies (since May 11, 1889), Snouck finally returned to the Netherlands on March 12, 1906. He still has a role in providing advice to the Ministry of Colonization in The Hague Netherlands about dealing with Muslims and giving directions on Islamic law. A collection of his works published in 1923 and 1927 along with the arrival of retirement. In the years ahead of his death, Snouck was a lot of writing in the Dutch media about Arab and Islamic issues. He died in Leiden on June 26, 1936 (Witkam, 2012: 152).

After the death of Snouck, many scholars responded to a figure called as the father of Islamic studies in Indonesia. His ability to master around twelve languages would almost be matched by later scholars. However, besides pitched praise writing, some criticisms were also given by Benda, Waardenburg and Wertheim related to Snouck with Dutch colonial government. Yet, critical debate about Snouck was more sharply in 1979, especially among van Koningsveld, Schroder, Graf and Witkam. Prominent debate over the issue of Snouck's Islamic motifs and morality in treating 
his wife and children in the Dutch East Indies (van Koningsveld, 1989: 36; Carvalho, 2010: 96). A number of scholars also focused on Snouck's contribution to the study of Islam in Europe, the foundation of the Islamic policy in The Dutch East Indies, as in the handling of the war in Aceh and its role in addressing pan-Islamism (Benda, 1958: 338-47). One of the most controversial issues in the spotlight and scholars was the status, Islamic motifs and Snouck's family problems living in Indonesia. The debates on both issues become the focus of the next study.

\section{Snouck's Conversion to Islam and His Marriage}

All current Islamic jurisprudence school (madhāhib al-fiqh) agree that the status of Islam become one of the requirements that must be completed by men who want to marry a Muslim woman. Snouck would understand this provision since the beginning of the scientific contacts on Islam at the University of Leiden. Therefore, it can be understood when Snouck could successfully enter Mecca on his visiting to Arabia (August 1884-August 1885 ) after first circumcised and converted to Islam, witnessed by Raden Aboe Bakar Djajadiningrat, an employee of the Dutch consulate in Jeddah. In addition, he reportedly also "bought" a female slave of Ethiopia, and forced the abandonment of the pregnant condition (Witkam, 2012: 150). At this point, it is unclear why the colonial government did not question this hidden problem.

Islamic issues of Snouck in recent then trigger a number versions of stories that circulated among scholars. First, Schroder believed that Snouck really converted to Islam during stayed in Mecca and continued in the Dutch East Indies, but Snouck hid his Islam to his non-Muslim colleague. Second, the common version believed by Muslims in Indonesia, namely that Snouck was a Muslim even considered as a scholar. But, he abused his Islam 


\section{JAJANG A ROHMANA}

to colonial interests. Muslims in Indonesia called it a "hypocrite and a crook." Third, the views of Paul van 't Veer stated that Snouck basically has sympathy for Islam, in the midst of hatred most Christians in the faith. Fourth, the argument that has been held by van Koningsveld, that Snouck indeed behaves as a Muslim while in Mecca and The Dutch East Indies, but in fact, he was agnostic (belief in God but do not embrace any religion) (Carvalho, 2010: 107-8). Snouck as a Muslim been proven historically, but it seems the purpose of a Moslem who invited a lot of interpretations. Hasan Mustapa's letters confirm the truth as Muslims from Mecca and then went to The Dutch East Indies until return to the Netherlands. Therefore, we do not need to take God's right to judge the motive of his Islam.

Snouck motivation to become a Muslim often associated with his marriage issues to Sundanese women. It was considered with controversial issue. Snouck's marriage with Native woman while living in The Dutch East Indies (1889-1906). This had become big news in several newspapers as revealed by van Koningsveld in the 1980s (van Koningsveld, 1989: 156-70). Snouck believed to be married to Sangkana or Sangkanaresmi in 1890, a seventeen-year-old Sundanese girl. Sangkana was the daughter of Chief Penghulu of Ciamis, RH Mohammed Ta'ib of his wife named Nataresmi. Ta'ib still closed relatives with Raden Ayu Lasmitakusuma, Ciamis Regent's wife, R. Arya Kusumabrata. Raden Ayu was what holds many of his extended family, including Sangkana to marry with Snouck (van Koningsveld, 1989: 220). Snouck's marriage with Sangkana held in Ciamis with Islamic wedding ceremony. Some newspapers covered the marriage, such as Soerabaja-courant, De Locomotief, Bataviaasch Het Nieuwsblad, De Standaard and others. Some news tended to be confusing with mentioning a Chief Penghulu's girl of Sumedang, RH Mohammed Adra'i. The newspaper De 
Standaard dated February 11, 1890, for instance, proclaimed Snouck's marriage:

Weer duiken omtrent Dr. Snouck berichten op, als vroeger ook zijn reeds in ounces blad tegengesproken. Aan het Bat. Thans wordt ten stelligste Nieuwsblad uit de Freanger geschreven, dat Dr. C. Snouck volgens Mahomedaanschen rite den in de moskee in het huwelijk is getreden met de dochter van den hoold-panghoeloe van Tjiamies. Door de Regeering is aan Dr. Snouck opgedragen, te onderdeken of en zoo ja, welke regelen zouden gesteld kunnen worden voor het toezicht op de Mohamedaansche geestelijken en op het Moh. Godsdienstig Onderwijs, en de resultaten van dat Onderzoek, waarvan zjin het zal ook afhankelijk Antwoord op de vraag aan het toezicht cq wie zou zijn op te dragen, aan de regie- ring mede te Deelen (Wormser, 1890, De Standaard, No. 5497, Amsterdam, Dinsdag February 11).

What this means: Once again steeped in the message of Dr. Snouck, as previously has been denied in our magazine. In Batavia Nieuwsblad has been written from Priangan, Dr. C. Snouck followed the religious rites of Muhammad in the mosque in a marriage with the Chief Penghulu's daughter of Ciamis. The government instructed Dr. Snouck to consider whether, and if so there are rules that can be set to monitor the scholars of Islam, the teachings of Muhammad and religious education. The results of the investigation will also greatly depend on the answer to the question that results of the monitoring will be continued and given to the government.

Snouck's marriage news reported by some newspapers was denied by the Governor General. He gave an answer to the Minister of Colonies in the Netherlands because it would greatly affect the proposal in order to fixed Snouck as a government advisor in The Dutch East Indies (van Koningsveld, 1989: 210). Not only the Governor General, Snouck denied the confusion of a newspaper report. He never reviewed this matter in his diary. There was no letter from the approximately 1000 undeclared 


\section{JAJANG A ROHMANA}

letters explain his Indies marriage or the children in The Dutch East Indies. Snouck mentioned the only woman whom he married in the Netherlands in 1910 was Ida Maria Oort and had a daughter (van Koningsveld, 1989: 124, 221). Snouck declared the wedding announcements in Ciamis as a form of idiocy and does not have an inner conviction. Snouck also stated that the wedding held between Chief Penghulu's daughter and a clerk. His presence in Ciamis aimed to conduct a study on the wedding ceremony.

However, the denial ultimately could not cover up the truth of the marriage. Scholars like van Koningsveld believed that marriage and confirmed directly on the descent of Snouck. R. Joesoef, a retired police commissioner of the Republic of Indonesia, stated that Snouck's marriage with Sangkana has granted four children, namely Salmah Emah (born late 1890), Oemar (born 1892), Aminah (born late 1893) and Ibrahim (31 December 1894-1976). Salmah Emah's name was given by Snouck by taking the name of Zanzibar princess, Salme Emily. Van Koningsveld also received information from former employees of pangrehpraja in The Dutch East Indies, Daniel van der Meulen explained that a Snouck' boy, namely Ibrahim, working in his office in Palembang (van Koningsveld, 1989: 160). In addition, some direct investigations to Ciamis around 2003 were founded a grave of R. Ibrahim in the special burial of Chief Penghulu's descent in Warungasem Ciamis (Tempo Team, 2011: 83).

Not only Sangkana's marriage information, but R. Joesoef also informed Snouck's subsequent marriage in 1898 with another Sundanese woman, Siti Sadijah (1885-1974). This marriage took place after Sangkana died before giving birth her fifth child in 1895. Snouck married Siti Sadijah when she was thirteen years old. She was the daughter of the vice Chief Penghulu of Bandung, RH Muhammad Su'eb or Kalipah Apo, from his 
wife Siti Khadidjah. Apo Kalipah also known as Sunda song best interpreter at his time. The marriage of Siti Sadijah and Snouck arranged by Haji Hasan Mustapa, the Chief Penghulu of Bandung. He later had a son, named R. Joesoef (born 1905) who become an informant for the main source of van Koningsveld's article (van Koningsveld, 1989: 162, 223). R. Joesoef married the daughter of Bandung Regent, RAA Wiranatakoesoema (18881965). He had five children, one of whom was Eddy Joesoef, a grandchild of Snouck who known as a national badminton player. In 1958, Eddy Joesoef won the Thomas Cup in Singapore (Jahroni 2012; Tempo Team 2011, 84).

Among colonial officials, there were strong tendencies oppose interracial marriage, especially among Europeans with $\mathrm{Na}$ tive woman or man. However, these rules did not entirely absolute, because the civil law applicable to the Europeans allows binding marriage contract with the Indigenous women and their children regarded as Europeans. But the colonial governments at that time, the marriage between Europeans and Native woman or man means tarnish European status which concerned with the difficulties in getting career (van Koningsveld, 1989: 156).

The bond between European and Native woman is often marked by an unofficial tie to live together or commonly known as concubine age involving Nyai. They were taken into housekeeper European masters and slept with them. They have born children who have the Indo-European hybridist race and culture and have a higher status in the appeal of his own mother. These children have European status if their Europeans father recognized them and embedded a family name. But, if it is not recognized by the father, then they are referred back to their original family of his mother and had no rights as Europeans (Hellwig, 2010: 161-2).

When the "good luck" inflicted to Indo-European children that because they were recognized by his father into European 


\section{JAJANG A ROHMANA}

family, but not so with the Nyai as her mother. The mother who became the mistress could be asked to leave at any time the European men want it, as experienced by Nyai Moeinah, one of the Javanese woman who became a mother and grandmother for large families Baay (Baay, 2010: xv-xix). The same thing also experienced by a Chinese Nyai, Goey La Nio, and some Sundanese women who become mistresses of Eduard Julius Kerkhoven (1834-1905) in the tea plantation area in Sukabumi, West Java which was partly told in the famous novel Hella S. Haasse (1918-2011), Heren van de thee (Haasse, 2005; Hellwig, 2010: 164-9).

However, sometimes, -it is very rarely probably- occurring also European men were converted to Islam and married a $\mathrm{Na}-$ tive woman according to Islamic law. He then considered to have become part of the family of the Indigenous communities, but children remain Natives, unless they get a determination from the colonial government to be treated equally with the Europeans (van Koningsveld, 1989: 157). The last thing happened to Snouck who marry Natives women like Siti Sadijah and Sangkana until having five children in Priangan.

Snouck who converted to Islam during in Mecca and has a Muslim name as Abdul Gaffar, married a Native woman and straight into Priangan aristocratic circle. Although until the return of Snouck to the Netherlands in 1906, Snouck's children never got a determination from the colonial government to be treated equally with the Europeans. The large families of $\mathrm{RH}$ Muhammad Ta'ib and Raden Ayu Lasmitakusuma in Ciamis and large families of RH Muhammad Su'eb or Kalipah Apo and Haji Hasan Mustapa in Bandung became a haven to Snouck and his children in Priangan aristocratic circle. Raden, a title for Joesoef for example, become a clue that Snouck's children already considered to be part of Bandung aristocratic family, $\mathrm{Ka}$ - 
lipah Apo, even he descent from Snouck which is of European. In 1930, in an old photo, R. Joesoef which has European face seemed married with a native woman attended by his grandfather, Kalipah Apo and the bride's father, a Regent of Bandung R.A.A. Wiranatakoesoema, which attended in special day of the commissariat police (Kurnia, 2017: 24).

\section{About Cod. Or. 8952}

Manuscript Cod. Or. 8952 is the personal letters Hasan Mustapa on Snouck currently stored in Universsiteitsbibliotheek (UB) Leiden. Meanwhile, the letters reply of Snouck to Mustapa, according to van Koningsveld records, has been destroyed Mustapa's family. Hasan Mustapa's letters stored in a text file papers of Snouck collection, namely Cod. Or. 18097 and Cod. Or. 8952. The first is a collection of letters received by Snouck from a number of people in the early period, especially when $\mathrm{He}$ stayed in Jeddah and Batavia. These collections include letters from Hasan Mustapa while still serving in Kotaraja Aceh which aimed to Snouck in Batavia Weltevreden between the years of 1893-1895 (file 9 and 16) (Ali, 2004: 84). In other hand, Cod. Or. 8952 is a collection of letters received by Snouck when retired and returned to the Netherlands in 1906. It included a number of Hasan Mustapa's letters between the years of 19071923, when he was made a Chief Penghulu of Bandung, pensions until a few years before his death (the last letter dated 9 August 1923). There was a letter written when Mustapa still stayed in Kotaraja before his return to Bandung after no longer being a Chief Penghulu of Kotaraja. Mustapa's letters in Cod. Or. 8952 was the primary source in this article.

Manuscript Cod. Or. 8952 is not listed in various manuscript catalogs of UB Leiden, either Arabic manuscripts catalog or Sundanese script. In addition to the form of manuscripts, Snouck's 


\section{JAJANG A ROHMANA}

letters collections are also listed in online digital catalog version by Saskia van Bergen, Collection Christiaan Snouck Hurgronje Correspondence (Cod. Or. 8952 AB), University Library Special Collections, Leiden University, 2011 ("Universteitbibliotheek Leiden," https://socrates.leidenuniv.nl, accessed in 8/04/2013 at 17:00). Hasan Mustapa's letters contained in the order at Cod. Or. 8952 A No. 735-738 and can be accessed online directly. Here's the complete data of Hasan Mustapa's letters in Cod. Or. 8952:

\begin{tabular}{|c|c|c|c|c|}
\hline No. & Script code & $\begin{array}{c}\text { Serial } \\
\text { Number }\end{array}$ & Date Letter & Amount \\
\hline 1 & Or. 8952 A 735 & 1 & October $15^{\text {th }}, 1895$ & $1 \mathrm{p}$ \\
\hline 2 & Or. 8952 A 735 & $2-4$ & September $21^{\text {st }}, 1907$ & $1 \mathrm{p}+$ envelope \\
\hline 3 & Or. 8952 A 735 & $5-8$ & January $1^{\text {st }}, 1911$ & $2 \mathrm{p}+$ envelope \\
\hline 4 & Or. 8952 A 735 & $9-11$ & February $23^{\text {rd }}, 1911$ & $1 \mathrm{p}+$ envelope \\
\hline 5 & Or. 8952 A 735 & $12-15$ & April $15^{\text {th }}, 1911$ & $2 \mathrm{p}+$ envelope \\
\hline 6 & Or. 8952 A 736 & $1-5$ & January $27^{\text {th }}, 1912$ & $5 \mathrm{p}$ \\
\hline 7 & Or. 8952 A 736 & $6-12$ & March $29^{\text {th }}, 1912$ & $4 \mathrm{p}+$ envelope \\
\hline 8 & Or. 8952 A 736 & $13-14$ & September 13rd,1912 & $2 \mathrm{p}$ \\
\hline 9 & Or. 8952 A 737 & $1-6$ & October $14^{\text {th }}, 1913$ & $6 \mathrm{p}$ \\
\hline 10 & Or. 8952 A 737 & 7 & October $25^{\text {th }}, 1913$ & $1 \mathrm{p}$ \\
\hline 11 & Or. 8952 A 737 & $8-9$ & November $4^{\text {th }}, 1913$ & $2 \mathrm{p}$ \\
\hline 12 & Or. 8952 A 737 & $10-14$ & October $12^{\text {nd }}, 1915$ & $5 \mathrm{p}$ \\
\hline 13 & Or. 8952 A 737 & $15-16$ & May $7^{\text {th }}, 1916$ & $2 \mathrm{p}$ \\
\hline 14 & Or. 8952 A 738 & $1-5$ & July 21 $1^{\text {st }}, 1917$ & $5 \mathrm{p}$ \\
\hline 15 & Or. 8952 A 738 & $6-9$ & March $9^{\text {th }}, 1920$ & $4 \mathrm{p}$ \\
\hline 16 & Or. 8952 A 738 & $10-11$ & January $1^{\text {st }}, 1921$ & $2 \mathrm{p}$ \\
\hline 17 & Or. 8952 A 738 & $12-14$ & February $10^{\text {th }}, 1923$ & $1 \mathrm{p}+$ envelope \\
\hline 18 & Or. 8952 A 738 & $15-18$ & August $9^{\text {th }}, 1923$ & $2 \mathrm{p}+$ envelope \\
\hline
\end{tabular}

Hasan Mustapa's name as the author of the letter was generally known from letterhead, Mustapa photograph on a number of letters beginning and his signatures. Several letters written note from an official letter with the letterhead name " $\mathrm{H}$. Hasan 
Moestapa, Hoofd Penghulu of Bandoeng” printed at the top left corner of the letter. The Hoofd Penghulu of Bandoeng was $\mathrm{Mu}-$ stapa's positions from 1895 to 1918. In some letters also appeared typical photo of Mustapa who wore a head covering. In addition, other important features of Mustapa's letter appeared in the signatures were always listed at the end of the letter. Generally, the whole signatures are identical. Almost all the front pages were also a pencil inscription that included the name of H. Hasan Moestapa Bandoeng with Latin characters. The posts would be given later as additional markers. It was unclear do the written added by Snouck, R.A Kern or the curator of Leiden library.

All of Mustapa's letters in Cod.Or. 8952 used language and Arabic script. Sometimes in some parts of the letters there was a quote or phrase using Sundanese language or Dutch. Arabic script tended to use khat riq'ah. The paper used was unlined paper. Each page generally consisted of 25 lines. The number of pages of each letter varies from 1-6 pages of letter. The page number listed at the top right corner of the letter. Some letters accompanied by an official envelope and number of them may be lost. The entire letter is now available in digital format. As shown in the above table, the letters from Mustapa in Or. 8952 written in two periods. It was the period when Mustapa become a Chief Penghulu of Bandung and after his retirement phase. It is known from the date of the letter.

\section{Snouck' Family News in Hasan Mustapa's Letters (Cod. Or.} 8952)

The news about the private problem of Snouck's family in Priangan, had been described by van Koningsveld since the 1980s. However, the explanation given is likely based on oral sources (oral history) from one of Snouck's boys, namely R. Joesoef. In 


\section{JAJANG A ROHMANA}

addition, he might also used a source in the form of letters from Snouck's children (Salmah Emah, Oemar, Aminah, and Ibrahim) that were sent from Ciamis to the Netherlands. According to him, the names of Snouck's children appeared from the list of Snouck's archived letters collection in Leiden UB which was sent from Ciamis. The letters came from the period of time after his return to the Netherlands in 1906. Until 1997, the UB Leiden did not allow to broadcast the letters (van Koningsveld, 1989: 152-3). This study attempted to use other sources to strengthen the information about Snouck's family especially between the years 1911-1923. The information for some scholars considered controversial because they tend to be covered up not only by Snouck himself but also by the colonial authorities.

The strong evidence of Snouck's family existence in Priangan could be more clear and convincing, one of which referred to the personal letters of Hasan Mustapa to Snouck stored in UB Leiden with code Or. 8952. Inside, Snouck's close friend was reported about his wives and children condition that left behind in Priangan from time to time. Of the 17 Arabic letters which he sent from Bandung, Hasan Mustapa almost never missed gave the last information of his wife and children. Hasan Mustapa along with Raden Ayu Lasmitakusuma and Kalipah Apo were given that responsibility. Hasan Mustapa has been regarded as a brother and a very trust to pay attention to the family, both living in Bandung and Ciamis.

In a letter dated January $1^{\text {st }}, 1911$, Hasan Mustapa told that Emah, the eldest daughter of Snouck look for a mate but canceled to be married. He states:

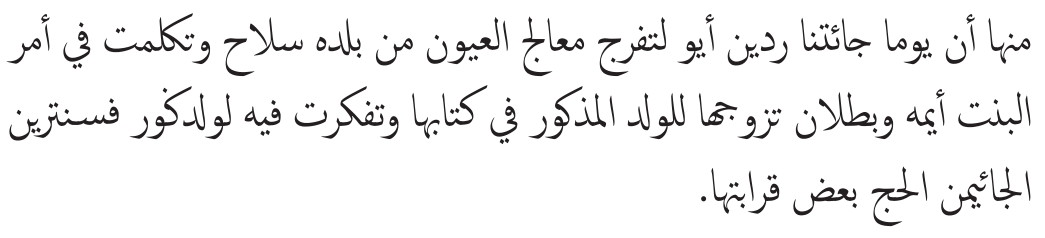


"Among other news, one day came to me Raden Ayu (Lasmitakusuma) to show the results of treated eyes from the Selah (?) He told the story of Emah, which canceled to be married to men who never mentioned in his letter. Raden Ayu thought about it, because he was a boy of Islamic boarding school' Teachers (Clerics) who most of his relatives (new) come from Hajj" (Moestapa, January 1 $\left.{ }^{\text {st }}, 1911 \mathrm{c}\right)$.

In the letter, Hasan Mustapa told about Emah, the eldest daughter of Snouck from Sangkana. Salmah Emah is her full name. She and other Sangkana's child (Oemar, Aminah, Ibrahim) were raised by Raden Ayu Lasmitakusuma in Ciamis after Snouck return to the Netherlands in 1906., Lasmitakusuma is the wife of Ciamis Regent Arya Kusuma Subrata, who was a close relative to the RH Muhamad Taib as the Ciamis Muslim Leader and Sangkana's father.

Comparing between years of Sangkana's marriage and Snouck (1890) to the date of the letter of Hasan Mustapa (January 1st, 1911), it meant that Emah's age was still a dozen years. It had become the general rule at that moment when girls married off in a very young age. But it was unclear why the marriage of Emah was canceled or whether she was at that time just matchmaking. The letters of Hasan Mustapa was just preached to Snouck about his eldest daughter's case.

Not only about Emah case, on another Mustapa Hasan's letter dated in February $23^{\text {rd }}$, 1911 was also the name of the other Snouck's children, namely Raden Joesoef:

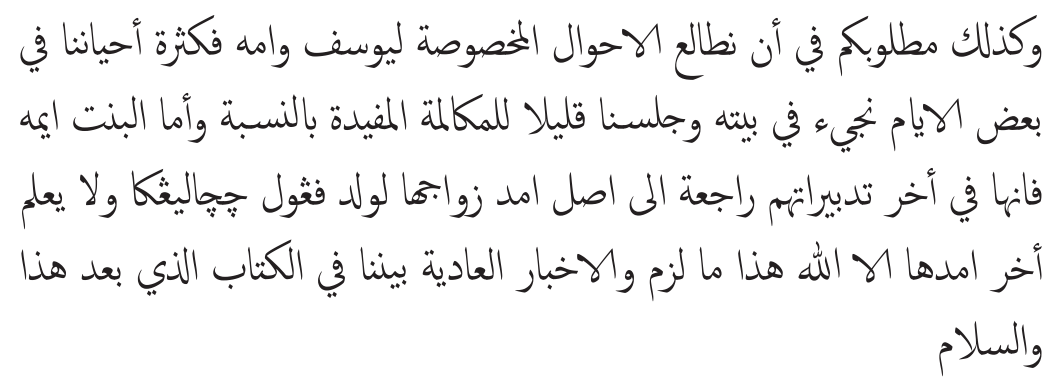




\section{JAJANG A ROHMANA}

"So did your request that I paid particular attention to the circumstances of Joesoef and his mother. Much of my life on most days was spent to come to his house. I often sat down to talk about something useful. As for your daughter, Emah, she almost finished preparing her marriage back its original deadline to the children of Cicalengka Muslim Leader. Nobody knows when the end of the wedding preparations other than Allah. Thus, the news informed as usual between us in this letter. Salam.” (Moestapa, February 23 ${ }^{\text {rd }}, 1911$ b).

In this letter, Hasan Mustapa said that he has met the demand of Snouck in paying attention to the family he left behind. He said that he quite often to visit Snouck's family in Bandung that were Joesoef and his mother, Siti Sadijah. Their house was not too far from Hasan Mustapa's residence which was in the area of Balonggede square, Bandung. Hasan Mustapa in another letter dated October $12^{\text {nd }}, 1915$ referred to its proximity with the "li qurbih wa mushāhadatih" (because of the close and easy to monitor) (Moestapa, October 12, 1915).

Moreover, Hasan Mustapa in the above letter also reported that Emah currently preparing to be married with a child of Cicalengka Muslim Leader. The certainty news about Emah's wedding was finally delivered two months later by his reply on April 15 ${ }^{\text {th }}, 1911$ :

$$
\begin{aligned}
& \text { اما بعد فقد استلمنا كتاكم المؤرخ با فبرواري في ذك سيرة البنت ايمه ثم جائتنا } \\
& \text { ردين ايو وتثاورت في امر زواجها ونهاية الكلام انه يصير الزواج واتفق الكلام }
\end{aligned}
$$

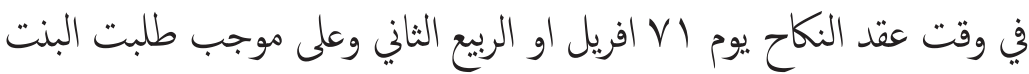

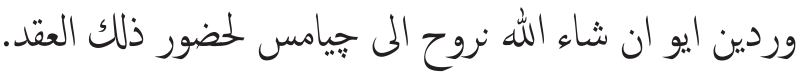

"I have received your letter on February $24^{\text {th }}, 1911$, which mentioned stories of your daughter, Emah, then came to me Raden Ayu (Lasmitakusuma) talked about her marriage. The end of the conversation ensured that marriage be performed and agreed the time of her marriage contract on April 17, 1911, or 
Rabi'ul Tsani. I was supposed to meet the demand for girls and the Raden Ayu. Insya Allah, I will come to Ciamis for attending the marriage ceremony" (Moestapa, April 15, 1911a).

In the letter, Hasan Mustapa assured Snouck that Emah, his eldest daughter, was ready to be married. He again dropped into Raden Ayu Lasmitakusuma to talk about it. Finally, it was agreed that the wedding will be held on April 17, 1911. Hasan Mustapa scheduled to come to Ciamis for attending the wedding.

The letter indicates that the proximity of both of them is not only reflected in the inclusion of Snouck into the family environment of indigenous officials (headman), but it also appears from the Snouck's trust to him to pay attention and keep his family in order to remain in the neighborhood's headman. It shows that Hasan Mustapa had a very deep fraternal relation. Snouck not only considered as a fellow Muslim but also be part of a big family. Hasan Mustapa for example sometimes greeted him with the words min al-akh al-'àshiq li muwājahati akhīh (this letter from the brother who wanted to meet with his brother).

The letters above also show that Raden Ayu Lasmitakusuma very honored with Hasan Mustapa personally. Raden Ayu certainly knew that Hasan Mustapa is a Snouck's close friend. He was the Chief Penghulu of Bandung who facilitated his marriage to his second wife, Siti Sadijah, the daughter of Kalipah Apo in Bandung. Therefore, it was natural that Raden Ayu as a nurse of Snouck's children told about their problems to him. As an elder person, Hasan Mustapa not only provided protection to his family's friend in Ciamis but also giving peace to him in Dutch. Hasan Mustapa finally attended the wedding of Emah with the child of Cicalengka's headman. He was also present when the marriage ceremony held in Ciamis. However, unfortunately Hasan Mustapa did not identify who was a trustee of the eldest Snouck's daughter. Do R. Muhammad Ta'ib, the Chief Penghulu 


\section{JAJANG A ROHMANA}

of Ciamis, as the adoptive grandfather who had been caring for Sangkana's children together with Raden Ayu Lasmitakusuma? Or Hasan Mustapa as Hoofd Bandung's headman which has been monitoring the situation and the way intentionally came to Ciamis to witness the wedding ceremony?

About ten years later, he gave the news to Snouck that he also attended the event slametan or kendurian of Emah child who newborn at home of headmen Cicalengka. It did not explain what number of Emah's child. He stated in a letter dated February $10^{\text {th }}, 1923$ :

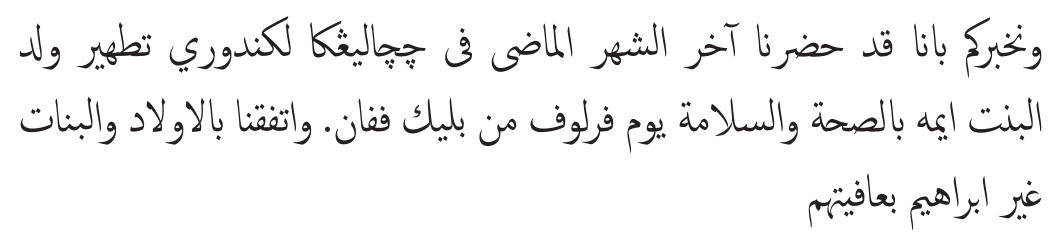

"And I gave the news to you that I already attend the event slametan at the end of last month, for 'cleaning' Emah's healthy boy at the moment (take) verluf (on leave) of Balik Papan. I watched the boys and daughters are all healthy, except Ibrahim" (Moestapa, February 10, 1923b).

Hasan Mustapa said that in the event of slametan for the newborn baby ('aqiqqah) in Cicalengka, Snouck's children both men and women are all healthy except Ibrahim. It was unclear whether Ibrahim got illness or did not exist in Cicalengka. Ibrahim really did not exist, because he was traveling to work in Palembang with van der Meulen as it is said by van Koningsveld (1989: 161).

The news about Snouck's children also notified by Hasan Mustapa in his letter dated January $27^{\text {th }}, 1912$ :

$$
\begin{aligned}
& \text { ومن الأخبار صحة الأولاد والبنات وعافيتهم ومنهم عمر هو تعلم في بتاوي على }
\end{aligned}
$$

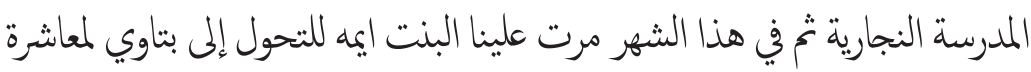




$$
\begin{aligned}
& \text { زو جها وسافرت معها ردين أيو وأح يوسف لترتيب بيتها في سلمباً. وأما يوسف }
\end{aligned}
$$

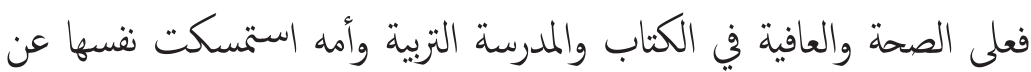

$$
\begin{aligned}
& \text { الخروج لمصاح العادية كما هي ذلك الذي أجبيناكأنها بعد أن وريناها وفسرنا معنى } \\
& \text { كتابك الذي استلمناه في ذكر تلك السيرة }
\end{aligned}
$$

"Among other news, all the children are in good health. Among them, Oemar is studying at Public School in Betawi. This month Emah visited my house before moving to Batavia accompanied her husband. Emah left with Raden Ayu and Joesoef's mother (Siti Sadijah), he would build a house in Salemba. Joesoef was also in good condition in terms of writing and the school. Joesoef's mother will initially refrain out traveling for contributing good customs, it makes me proud, it seems after my secret to him and explain the contents of your letter I received that says the trip" (Moestapa, January 27, 1912a).

Another Hasan Mustapa's letter that quite completed in mentioning Snouck's children was dated on March 29, 1912:

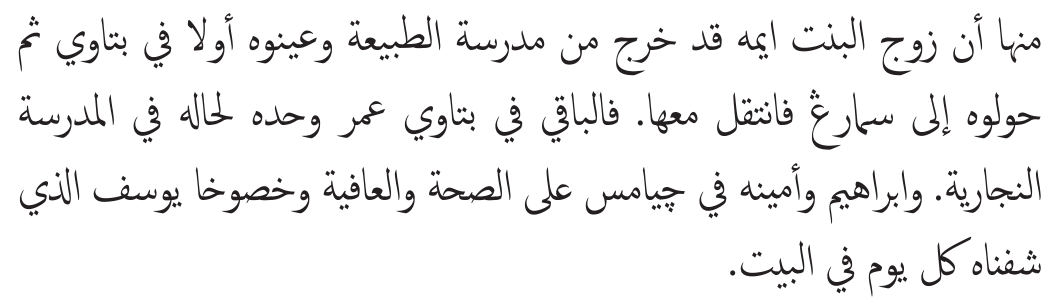

"Among other news, Emah's husband had graduated from the School of Medicine, and initially told to stay in Batavia, then moved to Semarang. Emah and her husband moved in. So, Oemar stays in Batavia alone, because he has been studied at Public School. As for Ibrahim and Amina who lived in Ciamis was also healthy condition, especially Joesoef that I noticed every day in his own home" (Moestapa, March 29, 1912b).

In the letter, Hasan Mustapa told comprehensively about the five children of Snouck. Those are Salmah Emah, Oemar Gandaprawira, Ibrahim, Aminah, and Joesoef. The news of Amina 


\section{JAJANG A ROHMANA}

R. Joesoef and reaffirmed in a letter dated in 2 Shawwal $1331 \mathrm{H}$ (September 1913):

$$
\text { صهمة وعافية الولد يوسف ولينا الأخبار بصحتنا وعافيتنا خصوصا الأولاد والبنات وتعين لنا دائما }
$$

"And I should proclaim the health problems, especially for your children, male and female. Of course, hopefully, they are in good health forever. Talking about Joesoef and his mother (Siti Sadijah), Joesoef had reached the age of a clean and a child with a tall stature. However, there are difficulties and fatigue that afflicts your daughter, Aminah who at the age she had married with a Police chief. Her husband was seriously ill, between life and death. The actual news about it should have been up from Raden Ayu (Lasmitakusuma)" (Moestapa, 2 Shawwal $1331 \mathrm{AH} /$ November 4, 1913b) (sic).

In the letter, Hasan Mustapa reported of Snouck's children's health especially Joesoef and Aminah. Joesoef getting bigger and the body is also high, it is likely resembled his father. Hasan Mustapa also cited problems afflicting Aminah, the third child of Snouck. He got into trouble because the newly married husband, a native police officer or Mantri Pulisi in Sukabumi, severe pain suddenly. This Hasan Mustapa's letter was probably written around September 1913. But in the text of the letter there is a pencil writing the record on Hasan Mustapa's letter (possibly by RA Kern) that actually mistakenly put the date of AD. He wrote 4, 1913 to the $2^{\text {nd }}$ of Shawwal $1331 \mathrm{H}$ written Hasan Mustapa.

The error of determining the date by which record Hasan Mustapa's letter was proven when reading further letter dated October 14, 1913. Primarily on the letter which associated with 
Aminah's husband who died. This occurred after Hasan Mustapa sent a letter earlier possibility of Shawwal 1331 dated 2 above. He stated:

$$
\begin{aligned}
& \text { ورجعنا إلى خبر الصحة والعافية العمومية ةالخصوصية خصوصا أهالينا وأهاليكم }
\end{aligned}
$$

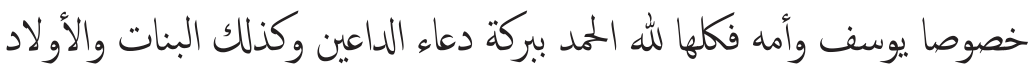

$$
\begin{aligned}
& \text { خصوصا أمينه المتوفى عنها زوبها بعد أن كتبنا كتابا سابقا }
\end{aligned}
$$

"And I return to explain the health information in general and specific, especially my family and you, in particular, Joesoef and her mother, all healthy thank God with blessing our praying. Likewise, girls and boys, especially Aminah that her husband died after I wrote the last letter ...” (Moestapa, October 14, 1913a).

Thus, the letter clearly showed that after Hasan Mustapa sent a letter dated 2 Shawwal $1331 \mathrm{H}$ or around the month of September 1913, Aminah's husband, a police official in Sukabumi, suddenly got serious illness. Then, in the next letter dated October 14, 1913, He was sent back the information about Aminah' husband who apparently died. Therefore, it is unlikely that the date of the letter Hasan Mustapa 2 Shawwal $1331 \mathrm{H}$ is sent after a letter dated October 14, 1913.

Furthermore, another Hasan Mustapa's letter which more clearly identified Snouck children was dated on March 9, 1920. He compared the number of Snouck's children with his own children. He said:

$$
\begin{aligned}
& \text { ونخبرك في آخر أيامنا آثارنا فى الدنيا المارة من الاولاد والبنات لكمهنا ه ولنا } 1 \text {. } \\
& \text { عسى ربنا ان بهديهم المى طريق السعادة الابدية بجاه الأحدية الصمدية. }
\end{aligned}
$$

"And I reported to you at the end of my days living in a world that's just a stopover, your sons and daughters were amounted to five people here, while my kids had been there for ten. May the Lord gives us instructions on the everlasting happiness way 


\section{JAJANG A ROHMANA}

only to The Almighty as a Place to return." (Moestapa, March 20, 1920).

So, on March 9, 1920, when the 68-year-old Hasan Mustapa, he compared the number of his own children who have reached ten, while Snouck's children in Priangan remain only five people. He proudly displays his children more than his friend. It could be a subject of study about Hasan Mustapa's family. Because he was at the end of his life (78 years) was rumored to have twelve children from his six-times marriage. Hasan Mustapa had children quite a lot of six-time marriage. First marriage with Nyimas Liut blessed with two sons named Muhammad and Mohammed Wardi Subki. Second, Siti Aisyah blessed with six children: Nonoh Maemunah, Toha Firdaus, Agam Ma'soem, Emong Soeleiman, Endoy Djumenah and Ekes Resmanah. Third, Rd. Ratna (Iyoh) had two children: Lembana and Dada Abdullah. Fourth, Rd. Đưa had two children: Rohbaeni and Kosasih. Fifth, the marriage with Palembang women, Nyayu Rodiah who has own daughter, namely Nyayu Pateman. Lastly, the marriage with Rd. Oyo Rokayah but not blessed with offspring (Kartini, 1985: 14$5)$.

In the last letter of Hasan Mustapa on Snouck, August 9th, 1923, or about seven years before Hasan Mustapa died, he preached already feeling out the responsibility of taking care of the boys and girls. They've considered independent, get married and have their own jobs. Perhaps this is also aimed at Snouck related to his children, such as Ibrahim who has been working in Bengkulu.

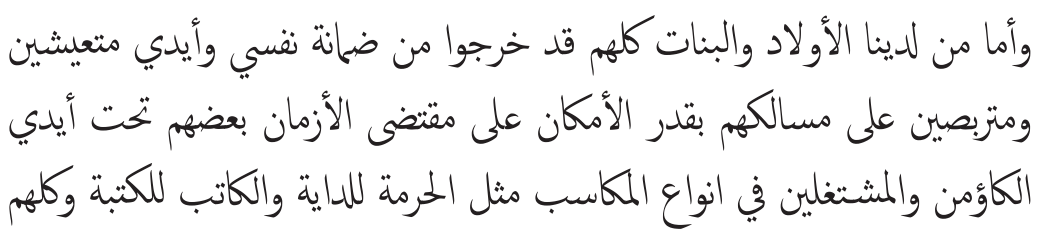




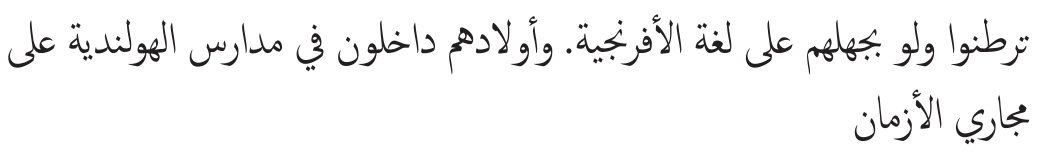

"Now, in front of me (today), boys and girls (us) everything is free from collateral and my responsibility. They live and pay attention to their own way of life as possible in accordance with the demands of the times. Most of them are under the responsibility of Kauman. They work in a variety of jobs such as keeping dayah and secretary in the library. They all speak a foreign language, even though they do not yet know the French language. Their children entered in the Netherlands schools in accordance with the times" (Moestapa, August 23, 1923a).

Thus some important news delivered by Hasan Mustapa in his letters about Snouck's wife and children in Priangan. All Snouck's children, those are Emah, Oemar, Aminah, Ibrahim including Joesoef and his mother mentioned in these letters. The information that is highly anticipated by Snouck as (former) husband and father of his flesh and blood. Snouck showed his seriousness by giving responsibility to his family despite the distance and situation are forced to separate them. His options to not take along his wife and children to the Netherlands presumably related to the problems will be faced in building his career as an advisor of Dutch government. A life choice that must be gone through in his helplessness, although with the risk of bad self-image to his personal morality that considered to just leave his wife and children.

\section{Conclusion}

This paper examines the controversy about Christiaan Snouck Hurgronje's wife and Indo-European descents in the early twentieth-century Priangan. It deals with a theme that sparked a debate among scholars in the 1980s regarding the Hurgronje's morality leaving his family in the Dutch East Indies in 1906. According to the writer, the issue must be read in 


\section{JAJANG A ROHMANA}

the context of Hurgronje's position as a colonial official who might be worried about his position since the rule of the colonial government did not allow a European official to marry an Indigenous woman. Violation of the rule can result in the loss of his career or position and the loss of recognition of his children to get the same rights as the Europeans. This is what Hurgronje's wife and children exactly experienced when he left them in Priangan, the Dutch East Indies, in the early twentieth century. Hurgronje, hence, cannot be considered completely irresponsible to his family. In fact, he continued to monitor the condition of his family through regular correspondence with his people in the Dutch East Indies, one of whom is Hasan Mustapa. Mustafa was Hurgronje's close friend and important informant who was given the responsibility of looking after his family. Many important events experienced by Hurgronje's wife and children were reported by Mustapa in the Cod. Or. 8952 manuscript. The manuscript, for example, informed the marriage of Hurgronje's eldest daughter named Emah in Ciamis, the birth of Emah's son (Hurgronje's grandson) in Cicalengka, Emah's move to Betawi to follow her husband pursuing his study in medicine, Oemar who was studying in a Public School in Betawi, Aminah's marriage with a police officer who suffered severe illness to death, the news about Joesoef and his mother named Siti Sadijah who lived in Bandung and so on. All information related to the Hurgronje's family as mentioned above is seen very important. That is, it proves the continuity of contact between the colonizer and the colonized through family news that is always awaited. Such a contact unites the two nations in a familial bond, i.e. between the nativized colonizer and the colonial Native. It also offers another perspective of the history of colonialism dealing with the fate of Indigenous women and their offspring amid the rise of the issue of Nyai and concubinage in the Dutch East Indies in the nineteenth century. 


\section{Bibliography}

Ali, Mufti. 2004. “A Study of Hasan Mustafa's Fatwa: It Is Incumbent upon the Indonesian Muslims to Be Loyal to the Dutch East Indies Government." Journal of the Pakistan Historical Society 52 (2): 67-84.

Baay, Reggie. 2010. Nyai \& Pergundikan Di Hindia Belanda (Nyai \& Concubinage in the Dutch East Indies). Edited by Siti Hertini Adiwoso. Depok: Komunitas Bambu.

Benda, Harry J. 1958. "Christiaan Snouck and the Foundations of the Islamic Dutch Policy in Indonesia." The Journal of Modern History 30 (4): 338-47.

Carvalho, Christina. 2010. "Christiaan Snouck Hurgronje: Biography and Perception.” Universiteit van Amsterdam.

Gobee, E. and Adriaanse, C. 1936. "Pengantar (Introduction)." In Nasihat-Nasihat C. Snouck Hurgronje Semasa Kepegawaiannya Kepada Pemerintah Hindia Belanda 1889-1936, edited by C. Gobee, E. and Adriaanse, 1991st ed. Jakarta: INIS.

Haasse, Hella S. 2005. Sang Juragan Teh (Heren van de Thee, the Owner of Tea Company). Edited by Indira Ismail. Jakarta: Gramedia.

Hellwig, Tineke. 2001. "Indonesia and the Malay World Asian Women in the Lives of Dutch Tea Planters : Two Narratives from West Java." Indonesia and the Malay World 29 (85): 161-79. doi:10.1080/13639810120102049.

Hurgronje, C. Snouck. 1880. Het Mekkaansche Feest. Leiden: Brill.

- 1902. Nota van Wenken Die Bij de Aanrakingen Met Hoofden En Bevolking van Het Gajoland Te Behartigen Zullen Zijn. Batavia: Landsdrukkerij.

- 1906. The Achehnese. Edited by translated by A.W.S. O’Sullivan. Vol. 2. Leiden: E.J. Brill. 1989. Parayaan Mekah (The Mecca Festivals). Edited by 


\section{JAJANG A ROHMANA}

Wiwin Triwinarti. Beck, H.L.; Kaptein, N.J.G.; Soeriawidjaja-Roring, Ny. P.A. Iskandar.; Wahyu. Jakarta: INIS.

- 2007. Mekka in the Latter Part of the 19th Century. Edited by translated by J.H. Monahan with an introduction by Jan Just Witkam. Leiden: Brill.

Jahroni, Jajang. 1999. "The Life and Mystical Thought of Haji Hasan Mustafa (1852-1930).” Leiden University.

- 2012. "Interview with Jajang Jahroni, a Researcher of Hasan Haji Mustapa, in Office PPIM UIN Syarif Hidayatullah Jakarta, on Saturday, September 3rd, 2012, at 09:00.”

Kartini, Tini. 1985. "Biografi Dan Karya Pujangga Haji Hasan Mustapa (A Biography and Works of A Sundanese Poet, Haji Hasan Mustapa)." Jakarta: Pusat Pembinaan dan Pengembangan Bahasa Departemen Pendidikan dan Kebudayaan.

Kartodirdjo, Sartono. 1988. "Surat Dari Wassenaar (the Letters from Wassenaar)." In Islam Dan Keturunan Arab Dalam Pemberontakan Melawan Belanda (Islam and Arab Descendants in the Revolt Against the Netherlands), edited by Hamid Algadri, 264-69. Bandung: Mizan.

Koningsveld, P.Sj. van. 1983. "Raden Jusuf Di Bandung Mengakhiri Kebungkamannya Sekitar Penikahan-Pernikahan Ayahnya, Christiaan Snouck Hurgronje (Jusuf Raden Bandung Ending His Silence about the Marriage-Marriage Her Father, Christiaan Snouck Hurgronje).” Kompas, February.

- 1989. Snouck Hurgronje Dan Islam, Delapan Karangan

Tentang Hidup Dan Karya Seorang Orientalis Zaman Kolonial (Snouck and Islam, Eight Essays on Life and Work A Period Orientalist Kolonial). Bandung: Girimukti Pasaka.

Kurnia, Atep. 2017. "Raratan Kalipah Apo (The Story of Kalipah Apo).” Pikiran Rakyat, February.

Moestapa, Haji Hasan. 1911a. "Arabic Letters from Bandung 
REREADING CHRISTIAAN SNOUCK HURGRONJE

(Correspondence with Snouck Hurgronje), 1911-1923, Cod. Or. 8952, April 15, 1911.” Leiden: UB Leiden University.

. 1911b. "Arabic Letters from Bandung (Correspondence with Snouck Hurgronje), 1911-1923, Cod. Or. 8952, February 23, 1911.” Leiden: UB Leiden University.

- 1911c. "Arabic Letters from Bandung (Correspondence with Snouck Hurgronje), 1911-1923, Cod. Or. 8952, January 1, 1911.” Leiden: UB Leiden University.

- 1912a. "Arabic Letters from Bandung (Correspondence with Snouck Hurgronje), 1911-1923, Cod. Or. 8952, January 27, 1912.” Leiden: UB Leiden University.

- 1912b. "Arabic Letters from Bandung (Correspondence with Snouck Hurgronje), 1911-1923, Cod. Or. 8952, March 29, 1912.” Leiden: UB Leiden University.

- 1913a. "Arabic Letters from Bandung (Correspondence with Snouck Hurgronje), 1911-1923, Cod. Or. 8952, October 14, 1913.” Leiden: UB Leiden University.

. 1913b. "Arabic Letters from Bandung (Correspondence with Snouck Hurgronje), 1911-1923, November 4, 1913 (Sic!).” Leiden: UB Leiden University.

- 1915. "Arabic Letters from Bandung (Correspondence with Snouck Hurgronje), 1911-1923, Cod. Or. 8952, October 12, 1915.” Leiden: UB Leiden University.

- 1920. "Arabic Letters from Bandung (Correspondence with Snouck Hurgronje), 1911-1923, Cod. Or. 8952, March 9, 1920.” Leiden: UB Leiden University.

. 1923a. "Arabic Letters from Bandung (Correspondence with Snouck Hurgronje), 1911-1923, Cod. Or. 8952, August 9, 1923.” Leiden: UB Leiden University.

—.1923b. "Arabic Letters from Bandung (Correspondence with Snouck Hurgronje), 1911-1923, Cod. Or. 8952, February 10, 1923.” Leiden: UB Leiden University. 


\section{JAJANG A ROHMANA}

Rohmana, Jajang A. 2012. "Sundanese Sufi Literature and Local Islamic Identity: A Contribution of Haji Hasan Mustapa's Dangding." Al-Jami'ah: Journal of Islamic Studies 50 (1): 303-27.

- 2015. "A Sundanese Story of Hajj in the Colonial Period: Haji Hasan Mustapa's Dangding on Pilgrimage to Mecca." Heritage of Nusantara 4 (2): 273-312.

—. 2016. "Persahabatan Penjajah Dan Bangsa Jajahan Di Hindia Belanda: C. Snouck Hurgronje Dan Haji Hasan Mustapa (the Friendship between Invaders and Its Colonies in the Dutch East Indies: C. Snouck Hurgronje and Haji Hasan Mustapa).” Afkaruna 12 (2): 144-68. doi:10.18196/AIIJIS.2016.0060.144-168.

Sabiq, Sayyid. n.d. Fiqh Al-Sunnah (Islamic Jurisprudence of Muhammad's Tradition). Vol. 2. Kairo: Al-Fath li I'lam al-'Arabi.

Said, Edward. 1994. Culture and Imperialism. New York: Vintage Book.

Tempo Team. 2011. “Anak Cucu Snouck Di Indonesia (Snouck's Children and Grandchildren in Indonesia)." In Daud Beureueh, Pejuang Kemerdekaan Yang Memberontak (Daud Beureueh, the Rebel Freedom Fighters), edited by Tim Tempo. Jakarta: KPG.

“Universteitbibliotheek Leiden.” 2011. https://socrates.leidenuniv.nl.

Witkam, Jan Just. 2007. “Introduction.” In Mekka in the Latter Part of the 19th Century, edited by J.H. Monahan (Trans.). Leiden: Brill.

_. 2012. "Christiaan Snouck Hurgronje." In Orientalist Writers, Dictionary of Literary Biography, edited by Dwayne A. Fitzpatrick, Coeli. \& Tunstall, 366th ed. Detroit: Gale.

Wormser, J.A. 1890. “Wit Indie.” De Standaard. 